\title{
CEREBRAL EVOKED POTENTIALS IN HUMAN CHRONIC CHAGAS' DISEASE
}

\author{
O. M. GENOVESE - OLGA P. SANZ - J. CORREALE \\ MARCELA GARCIA ERRO - R. E.P. SICA
}

\begin{abstract}
SUMMARY - Seventy five patients with the diagnosis of chronic Chagas' disease were studied by employing EPs techniques. Two of them had delayed arrival of the signal to the Erb's point and one to the spinal cord when looking at SEPS. Two patients had increment of the time interval between waves Ist and IIIrd, when studying PEATs. 'These findings were interpreted as due to perioheral nerve fibers damage, a feature described in previous papers. The most striking finding was the prolonged time interval between waves N13 and N20 (SEPs) found in two patients and between waves IIIrd and Vth (PEAT) seen in 7 affected subjects. These observations suggested the development of some sort of CNs involvement, perhaps related to myelin damage, in patients who reached the chronic state of the infection.
\end{abstract}

\section{Estudio de potenciales evocados cerebrales en la enfermedad de Chagas crónica humana.}

RESUMEN - Setenta y cinco pacientes con el diagnóstico de enfermedad de Chagas crónica fueron estudiados con el empleo de los potenciales evocados cerebrales. Tres de ellos tuvieron retardo del arribo de la senal al punto de Frb ó al ingreso medular en los potenciales evocados somatosensitivos (PESS). Dos pacientes presentaron incremento del intervalo entre las ondas I y III en los potenciales evocados auditivos de tronco (PEAT). Estos hailazgos fueron interpretados como debidos al dano en la fibra nerviosa periférica, un hecho descriptn er trabajos previos. El hallazgo mas sorprendente fue la prolongación del intervalo de tiempo entre las ondas N13-N20 en los PESS, hallandose en dos pacientes y entre las ondas III y $V$ en los PEAT en 7 sujetos. Estas observaciones sugieren de algun modo, el compromiso de sistema nervioso central, quizás relacionado al dano de la mielina, en pacientes en estadio crónico de la infección.

Nervous system damage is known to occur in chronic Chagas' disease either in humans $\mathbf{1 , 2}$ or in experimental animals 3,4 . Much of the work has been done searching for peripheral nervous system involvement in this illness, and currently evidences have been accumulated supporting the insult of the spinal alpha motoneurone soma 5 , the posterior root ganglia neurones 6 and the peripheral nerve fibers 6 . Howewer, as far as we know none study has been carried out in humans looking for an eventual damage of their central nervous system (CNS), though detailed analysis of CNS changes has been carried out in animals chronically infected, in which loss of Purkinje cells 3 and of hypothalamic neurones 2 have been described.

The aim of the present investigation has been to make a gross approach to the CNS of patients with chronic Chagas' disease by employing a non-invasive electrophysiological method as a first attempt for detecting eventual existing abnormalities.

Sección Electroneurofisiología Clinica, División Neurología, Hospital Ramos Mejía, Buenos Aires. 


\section{MATERIAL AND METHODS}

Patients - The study invelved 75 subjects with the diagnosis of chronic Chagas' disease made at the Instituto Nacional de Diagnostico e Investigacion de la Enfermedad de Chagas in Buenos Aires. For these purposes three serological tests were employed, namely: 1. immunofluorescence; 2. complement fixation; 3. haemoagglutination. Only were accepted for this investigation those patients who showed positiveness of, at the least, two tests. Thirty were females and 45 were males, their ages ranged between 18 and 57 years. Coincidental causes of neurological disorders were eliminated from the study by rejecting patients over 60 years old (?) and others who had had toxic or metabolic disorders known to induce nervous system damage. Those patients with any genetic disease or other parasitic illness were also excluded. Controls - A total of 54 healthy and non selected subjects, not infected with Trypanasoma cruzi, whose ages ranged between 18 and 59 years, served as controls.

Electrophysiological techniques - Evoked potentials were recorded by employing a ATI (type 960/4) averager machine.

1. Somatosensory evoked potentials (SEPs). Stimulation: Electrical stimuli were applied percutaneously to the median nerve at the wrist. The pulses were $0.1 \mathrm{~ms}$ duration and their intensity was progressively increased until a weak twitch of the thenar muscles could be observed. The number of stimuli delivered was the necessary to evoke a well defined SEP and varied between 120 and 500 . The frequency of the discharge was $2 \mathrm{~Hz}$. Recording: Fine platinum electrodes were employed as recording and reference electrodes. Recording electrodes were positioned at three different locations according to the type of recorded potential: a) contralateral (to the stimulus) somatosensory area (C3 or C4) (71 pacients), b) nuchal midline $C 6$ (40 patients), and c) Erb's point ipsilateral to the stimulus (40 patients). Scalp and spine electrodes were refered to another electrode situated at Fz position, while the Erb electrode was coupled to another electrode positioned at the contralateral C3 or C4 locations.

2. Brain stem auditory evoked potentials. Altogether 30 patients were studied with this technique. Stimulation: Conventional audiometric earphones were applied to both ears. Monoaural stimulation, employing click stimuli with white masking noise delivered to the opposite ear was employed. The repetition rate was $11 \mathrm{~Hz}$ and the click intensity was adjusted to $80 \mathrm{~dB}$. Two thousand pulses were delivered for each recording. Recording: The stigmatic electrode was a fine platinum needle inserted in the scalp at $\mathrm{Cz}$ position refered to an electrode placed at A1 or A2 locations ipsilateral to the stimulus. Every patient was submitted to audiometric evoked responses previously to the brain stem auditory evoked potentials investigations; all the figures obtained were normal.

3. Visual evoked potentials. Twenty five patients were submitted to this particular investigation. Stimulation: The subject was sitting in a comfortable chair and positioned $1 \mathrm{~m}$ from a TV screen with one eye patched and the gaze fixed on a dot in the center of the screen. The screen subtended an angle of 15 . Check board pattern was reversed one every second and 50 stimuli were delivered. Recording: The recording electrode was also a fine platinum electrode which was positioned at $\mathrm{Oz}$ and refered to another needle situated at $\mathrm{Cz}$.

Treatment of the results - Difference between two mean values was estimated by the Student ' $t$ ' test. Throughout the text means are given with 1 SD.

\section{RESULTS}

1. Somatosensory evoked potential - When individual values were analyzed, it could be seen that some few patients were situated outside of the control range. So, one of them had a prolonged $\mathrm{Ng}$ wave $(12.28 \mathrm{~ms})$, two others disclosed prolonged N13 (15.32 ms and $16.76 \mathrm{~ms})$ and $\mathrm{N} 20(21.40 \mathrm{~ms}$ and $21.41 \mathrm{~ms})$ waves, while other two showed increased intervals between waves $\mathrm{N} 13$ and $\mathrm{N} 20(7.56 \mathrm{~ms}$ and $8.32 \mathrm{~ms})$. The difference between these individual values and the control means were of more than two SD, except for a single figure $(7.56 \mathrm{~ms}$ ) which differed from the control mean by $1.78 \mathrm{SD}$ (for comparison, see Table 1). Both patients snowing prolonged central conduction time between N13 and N20 waves disclosed normal brain stem potentials when explored with auditory stimulation. All the other patients had values whithin the control limits and, when they were compared with controls, no differences were found between barred means for each point of recording (Table 1). 


\begin{tabular}{|c|c|c|c|}
\hline & Controls & Patients A & $\begin{array}{c}\text { Patients } \mathbf{B} \\
\text { (individual values) }\end{array}$ \\
\hline $\begin{array}{l}\text { NEP's latency } \\
\text { (ms) }\end{array}$ & $\begin{array}{r}9.63 \pm 0.89 \\
(7.32-11.32)\end{array}$ & $\begin{array}{c}9.63 \pm 0.81 \\
(8.12-11.16) \\
p: \mathrm{n} / \mathrm{s}\end{array}$ & 12.28 \\
\hline $\begin{array}{l}\text { N13 latency } \\
\text { (ms) }\end{array}$ & $\begin{array}{c}13.27 \pm 0.89 \\
(11.48-15)\end{array}$ & $\begin{array}{c}12.86 \pm 0.98 \\
(10.56-14.52) \\
p: n / s\end{array}$ & $15.32-16.76$ \\
\hline $\begin{array}{l}\text { N20 latency } \\
(\mathrm{ms})\end{array}$ & $\begin{array}{c}18.92 \pm 0.88 \\
(16.56-20.80)\end{array}$ & $\begin{array}{c}18.38 \pm 0.92 \\
(16.64-20.16) \\
p: n / s\end{array}$ & $21.40-21.41$ \\
\hline $\begin{array}{l}\text { N20 P22 amplitude } \\
(\mathrm{ms})\end{array}$ & $\begin{array}{l}2.69 \pm 1.5 \\
(0.18-5.56)\end{array}$ & $\begin{array}{c}2.81 \pm 1.47 \\
(0.53-6.70) \\
p: n / s\end{array}$ & \\
\hline $\begin{array}{c}\mathrm{N} 13-\mathrm{N} 20 \\
(\mathrm{~ms})\end{array}$ & $\begin{array}{l}5.58 \pm 1.10 \\
(3.08-7.40)\end{array}$ & $\begin{array}{c}5.38 \pm 0.65 \\
(4.04-6.92) \\
\text { p:n/s }\end{array}$ & $7.56-8.32$ \\
\hline
\end{tabular}

Table 1 - Somatosensory evoked potentials in patients with chronic Chagas disease. A: patients with values within the control range. B: patients with values out of the control range. NEP's: nerve evoked potential, recorded at the Erb's point. Between brackets the lower and upper limits.

\begin{tabular}{|c|c|c|c|}
\hline $\begin{array}{l}\text { Latency [ms] } \\
\text { Wave }\end{array}$ & Controls & Patients A & $\begin{array}{c}\text { Putients } B \\
\text { (individual values) }\end{array}$ \\
\hline 1 & $\begin{array}{c}1.44 \pm 0.14 \\
(1.2-1.7)\end{array}$ & $\begin{array}{c}1.47 \pm 0.12 \\
(1.18-1.7) \\
p: n / s\end{array}$ & \\
\hline 11 & $\begin{array}{l}2.57 \pm 0.18 \\
(2.2-2.8)\end{array}$ & $\begin{array}{c}2.57 \pm 0.21 \\
(1.8-2.8) \\
p: n / s\end{array}$ & $3.01-3.04$ \\
\hline III & $\begin{array}{c}3.66 \pm 0.17 \\
(3.3-4.1)\end{array}$ & $\begin{array}{c}3.66 \pm 0.23 \\
(2.6-4.1) \\
p: n / s\end{array}$ & \\
\hline IV & $\begin{array}{c}4.81 \pm 0.19 \\
(4.5-5.1)\end{array}$ & $\begin{array}{c}4.81 \pm 0.26 \\
(3.9-5.1) \\
p: n / s\end{array}$ & $\mathbf{5 . 3 6}-\mathbf{5 . 3 7}$ \\
\hline $\mathrm{V}$ & $\begin{array}{c}5.54 \pm 0.19 \\
(5.3-5.9)\end{array}$ & $\begin{array}{c}5.59 \pm 0.23 \\
(5.0-5.9) \\
p: n / s\end{array}$ & 6.36 \\
\hline IU-V & $\begin{array}{c}5.48 \pm 0.24 \\
(5.1-5.9)\end{array}$ & $\begin{array}{c}5.34 \pm 0.24 \\
(4.86-5.7) \\
p: n / s\end{array}$ & \\
\hline $\begin{array}{c}\text { Interval [ms] } \\
\text { I-III }\end{array}$ & $\begin{array}{c}2.22 \pm 0.15 \\
(1.9-2.5)\end{array}$ & $\begin{array}{c}2.17 \pm 0.21 \\
(1.2-2.5) \\
\mathrm{p}: \mathrm{n} / \mathrm{s}\end{array}$ & $2.60-2.70$ \\
\hline III-V & $\begin{array}{c}1.85 \pm 0.16 \\
(1.6-2.1)\end{array}$ & $\begin{array}{c}1.77 \pm 0.25 \\
(1.2-2.1) \\
\text { p: n/s }\end{array}$ & $\begin{array}{l}2.20-2.22-2.30 \\
2.30-2.60-2.90 \\
3.00\end{array}$ \\
\hline
\end{tabular}

Table 2 - Brainsteam auditory evoked responses in patients with chronic chagas' disease. A: patients with values within the control range. B:-patients with values out of the control range. Between brackets the lower and upper limits. 
2. Brain steam auditory evoked potential - From the patients studied with this technique, 12 of them had one or more abnormal responses. Two patients showed prolonged latencies of the IInd (3.01 and $3.04 \mathrm{~ms})$ and IVth $(5.37$ and $5.86 \mathrm{~ms})$ waves; one of them had also a delayed Vth wave $(6.36 \mathrm{~ms})$ on one side; both patients had a slightly bilaterally prolonged Ist-IIIrd waves interval (2.6 and $2.7 \mathrm{~ms}$, respectively), while the time elapsing between waves IIIrd and Vth was normal in both of them. Seven other patients showed increment of the intervals between waves IIIrd and Vth on one side (2.2, 2.22, 2.3, 2.3, 2.6. 2.9 and $3.0 \mathrm{~ms}$, respectively): here too, the difference between these individual values and the control means were of more than two SD (for comparison, see Table 2). When comparing both sides, it was observed that good correspondence in latency values could be found in controls; so, the maximai discordance amounted to $0.4 \mathrm{~ms}$ for the second wave (Table 3); when the same procedure was followed with patients it was noted that some of them were beyond the normal maximal limits (Table 3). When working up the same sort of test for the intervals between waves Ist and IIIrd and between waves IIIrd and Vth, it was noted that altogether 8 patients were outside the normal values (Table 3). The remainder 18 patients had values well within the control range and their mean aid not significantly difier from controls (Table 2).

3. Visual evoked potential - None of the studied patients had abnormal values. Their means did not differ from the normal population (Table 4).

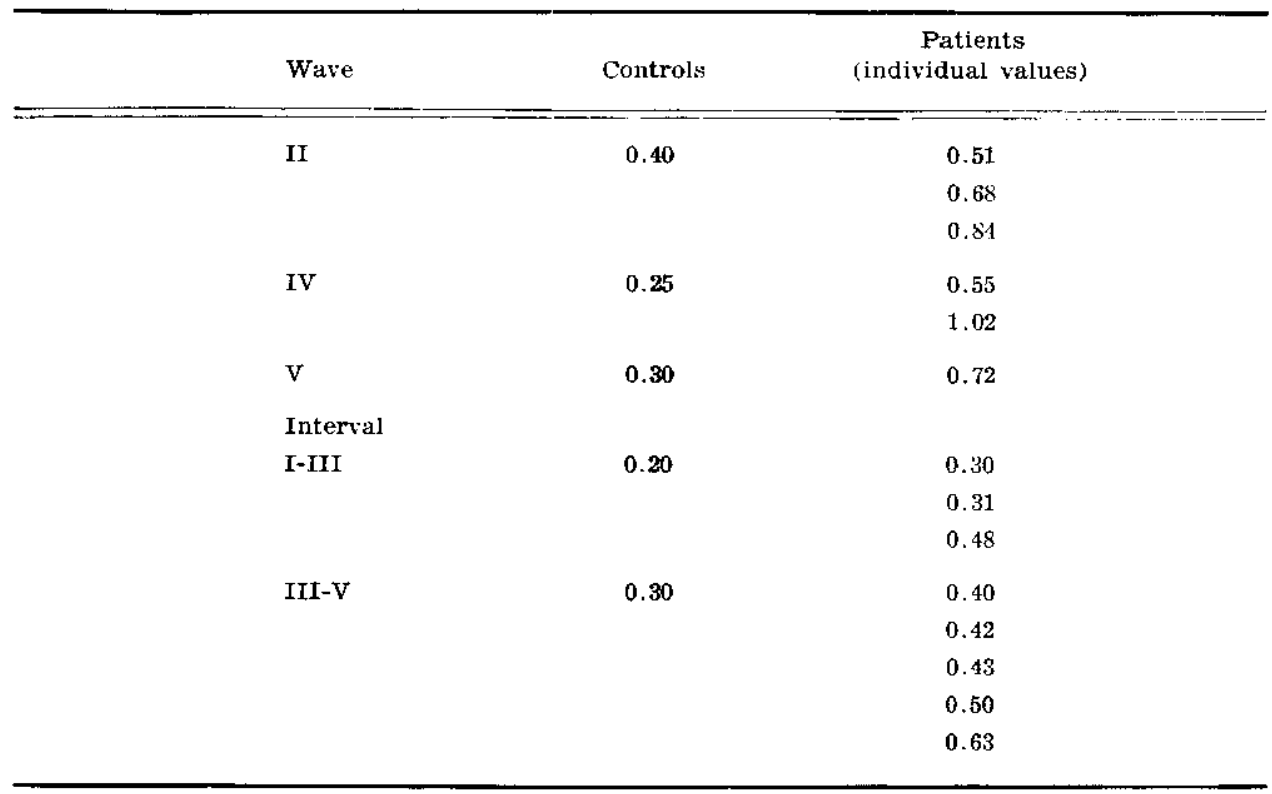

Table 3 - Differences between waves latencies and inter-wave intervals expressed in ms. Maximal values are given for controls in the central column. On the right hand column only the patients who had values above the normal upper limit. None patient showed abnormal values for waves $I$ and $I I I$.

\begin{tabular}{lccc}
\hline & Controls & Patients & $\mathrm{p}$ \\
\hline $\begin{array}{l}\text { P } 100 \text { latency } \\
\text { (ms) }\end{array}$ & $98.4 \pm 9.2$ & $91.22 \pm 7.23$ & $\mathrm{n} / \mathrm{s}$ \\
$\begin{array}{l}\text { P 100 amplitude } \\
\text { (uV) }\end{array}$ & $(81-\mathbf{1 1 3 )}$ & $(79-\mathbf{1 1 2})$ & $\mathrm{n} / \mathrm{s}$ \\
& $9.7 \pm \mathbf{5 . 6 9}$ & $5.7 \pm 3.75$ & $(2.5-18)$ \\
\end{tabular}

Table 4 - Visual evoked potentials in patients with chronic Chagas' disease. Between brackets the lower and upper limits. 


\section{COMMENTS}

Scatter and mild abnormalities were observed in the EPs obtained in patients with chronic Chagas' disease. Some of them, such as the delayed arrival of the signal to the Erb's point (N9, SEP) or to the spinal cord (N13, SEP) may be related to the impairment of the sensory fibers which was formerly recognized by Sica et al. 6 in patients affected by this condition. However, only three patients showed these abnormalities; this seems to be at variance with the findings of Sica et al. 6 who working on the peripheral nerve found that about $45 \%$ of the studied population had some sort of impairment. This discrepancy may be attributed to the different techniques imployed, being more sensitive for detecting sensory peripheral nerve damage the one used by Sica et al., while the methodology employed in the present paper allows to disclose just gross alterations in those fibers.

The prolonged interval hetween waves Ist and IIIrd may partially be due to involvement of the 8 th nerve, despite that same authors have recently postulated that involvement of the pons and/or medulla may produce similar findings 8 .

However, the most importante observation in this study was the prolonged interval seen between waves $\mathrm{N} 13$ and N20 in two patients when looking at SEPs and between the IIIrd and Vth waves in 7 affected subjects when studying PEATs. Both of these findings suggest that CNS may be altered in some patients who reached the chronic state of the infection. As far as we know, this is the first reference to this possibility in humans and might be related to some sort of impairement of the central myelin. Nevertheless, this theoretical myelin damage has to be quite mild, because none of the affected subjects showed cuntcal abnormal features.

Owe to the type of approach done and the technique used in this first study, no clues could be obtained for inferring the pathogenesis which may underlie those findings.

Acknowledgment - This investigation received financial support from the UNDP/Worla Bank/WHO Special Programme for Research and Training in Tropical Diseases.

\section{REFERENCES}

1. Brandâo HJ, Zulian R - Nerve cell depopulation in chrunic Chagas' disease: a quantitative study in the cerebellum. Rev Inst Med Trop São Paulo 8:281, 1966.

2. Britto Costa R, Gallina RA - IIipotálamo anterior na moléstia de chagas humana. Rev Inst Med Trop São Paulo 1:3:92, 1971.

3. Jardim E - Alteraçôes quantıtativas das celulas de Purkinje na moléstia de Chagas experimental no camundongo. Arq Neuro-Psiquiat (Sāo Paulo) 25:199, 1967.

4. Jardim E -- Moléstia de Chagas experimental no rato: parasitismo do núcleo de III par craniano. Rev Inst Med Trop Sāo Paulo 13:105, 1971.

5. Sanz OP, Ratusnu AF, Aristimuso GG, O'Neill EM, Sica REP - An electrophysiolosical investigation of skeletal muscle in human chronic Chagas' disease. Arq Neuro-Psiquiat (São Paulo) 36:319, 1978.

b. Sica REP, Filipini D, Panizza M, Fumo T, Basso S, Lazzari J, Molina HA - Involvement of the peripheral sensory nervous system in human chronic Chagas' disease. Medicina (Buenos Aires) $46: 662,1986$.

7. Sica REP, Sanz OP. Colombi A - The effects of ageing upon the human soleus muscle: an electrophysiological study. Medicina (Buenos Aires) 36:443, 1976.

8. Starr A, Achor $J$ - Auditory brain stem responses in neurological disease. Arch Neurol $32: 761,1975$. 